\title{
Manipulation of nitrogen leaching from tea field soil using a Trichoderma viride biofertilizer
}

\author{
Shengjun $\mathrm{Xu}^{1} \cdot$ Sining $\mathrm{Zhou}^{1} \cdot$ Shuanglong $\mathrm{Ma}^{2} \cdot$ Cancan Jiang ${ }^{1,3} \cdot$ Shanghua $\mathrm{Wu}^{1}$ • \\ Zhihui Bai $^{1} \cdot$ Guoqiang Zhuang ${ }^{1} \cdot$ Xuliang Zhuang ${ }^{1,3}$
}

Received: 19 May 2017 / Accepted: 26 September 2017 /Published online: 6 October 2017

(C) Springer-Verlag GmbH Germany 2017

\begin{abstract}
With the increasing use of chemical fertilizers, negative environmental impacts have greatly increased as a result from agricultural fields. The fungus Trichoderma viride used as a biofertilizer can efficiently reduce nitrous oxide $\left(\mathrm{N}_{2} \mathrm{O}\right)$ emissions from subtropical tea fields in southern China. In this paper, it was further found that $T$. viride biofertilizer could alleviate nitrogen $(\mathrm{N})$ leaching in tea fields. Gross $\mathrm{N}$ leaching was $1.51 \mathrm{~kg} \mathrm{ha}^{-1}$ year $^{-1}$ with no external fertilizer input, but when $225 \mathrm{~kg} \mathrm{~N} \mathrm{ha}^{-1}$ year $^{-1}$ was applied, it increased to $12.38 \mathrm{~kg} \mathrm{ha}^{-1}$ year $^{-1}$ using T. viride biofertilizer but $53.46 \mathrm{~kg} \mathrm{ha}^{-1}$ year $^{-1}$ using urea. Stepwise linear regression analysis identified the factors responsible for $\mathrm{N}$ leaching to be soil nitrate concentration and soil interflow, simulated here using the water balance simulation model (WaSiM-ETH). Finally, mass-scale production of T. viride biofertilizer from waste reutilization using sweet potato starch wastewater and rice straw was found to be cost-effective and feasible. These procedures could be considered a best management practice to
\end{abstract}

\section{S. J. Xu and S. N. Zhou contributed equally to this paper.}

Responsible editor: Philippe Garrigues

Shengjun $\mathrm{Xu}$

sjxu@rcees.ac.cn

Guoqiang Zhuang

gqzhuang@ rcees.ac.cn

1 Research Center for Eco-Environmental Sciences, Chinese Academy of Sciences, 18 Shuangqing Road, Haidian District, Beijing 100085, China

2 Key Laboratory of Pollution Processes and Environmental Criteria (Ministry of Education), College of Environmental Science and Engineering, Nankai University, Tianjin 300071, China

3 College of Resources and Environment, University of Chinese Academy of sciences, Beijing 100049, China reduce $\mathrm{N}$ leaching from tea fields in subtropical areas of central China and to reduce pollution from other agricultural waste products.

Keywords Tea field $\cdot$ Nitrogen leaching $\cdot$ Lysimeter experiment $\cdot$ Trichoderma viride biofertilizer - Waste reutilization $\cdot$ Biological control

\section{Introduction}

Covering a total area of 1.64 million ha in China, tea plantations have generated enormous economic profits and have tended to occupy lands that were primitively forest ( $\mathrm{Li}$ et al. 2011; Xu et al. 2014). To enhance tea yields and soil nutrients, various fertilizers (e.g., nitrogen fertilizers, potash fertilizers, nitrogen/phosphorus/potassium blends, and others) have been applied to tea field soil; therefore, tea plantations have consumed a considerable proportion of the total nutrient fertilizer consumed in China, from $0.54 \mathrm{Tg}$ in 1961 to $31 \mathrm{Tg}$ in 2014 (Sun et al. 2008; FAO 2016). The use of large amounts of nitrogenous fertilizer significantly contributed to nitrogen (N) losses as nitrous oxide $\left(\mathrm{N}_{2} \mathrm{O}\right)$ emissions to the atmosphere and $\mathrm{N}$ leaching into water. $\mathrm{N}_{2} \mathrm{O}$, well known as an ozone-depleting substance and greenhouse gas (Ravishankara et al. 2009; Sørensen and Jensen, 2013), is released into the atmosphere mainly through tillage processes, application of $\mathrm{N}$ fertilizers, or via nitrification and denitrification mediated by microorganisms (Palmer et al. 2014). Simultaneously, N leaching into surface water and groundwater is a kinetic process affected by various environmental factors (Sun et al. 2008), which can be classified into two categories, namely nitrate $\left(\mathrm{NO}_{3}{ }^{-}\right)$ leaching and ammonium $\left(\mathrm{NH}_{4}{ }^{+}\right)$leaching. However, it is mainly presented as $\mathrm{NO}_{3}{ }^{-}$leaching, firstly because $\mathrm{NH}_{4}{ }^{+}$can be easily oxidized to $\mathrm{NO}_{3}{ }^{-}$within several days or weeks under 
aerobic conditions and secondly because $\mathrm{NH}_{4}{ }^{+}$cations are readily absorbed onto anionic soil colloids, while $\mathrm{NO}_{3}{ }^{-}$ions are highly mobile (Sørensen and Jensen, 2013). Additionally, because of inappropriate fertilizer application and irrigation $(\mathrm{Li}$ et al. 2007), soil $\mathrm{N}$ can be readily washed off from agricultural fields and seep into the groundwater (vertical movement) or surface waters (horizontal movement). This leads to risks of both eutrophication and aquatic or anthropological toxicity, such as gastric and esophageal cancers (Gao et al. 2016). Therefore, a cost-effective measure is required to enhance crop yields and simultaneously reduce $\mathrm{N}$ losses, on the premise of maintaining soil fertility (Zhang et al. 2017).

A number of studies have reported chemical and physical methods to manipulate $\mathrm{N}$ leaching. For instance, applications of nitrification inhibitors (NIs) can mitigate both $\mathrm{N}_{2} \mathrm{O}$ emissions and $\mathrm{N}$ leaching by blocking the oxidation of $\mathrm{NH}_{4}{ }^{+}$to $\mathrm{NO}_{2}{ }^{-}$and then to $\mathrm{NO}_{3}{ }^{-}$in Nitrosomonas (Zerulla et al. 2001; Qiao et al., 2015; Wu et al. 2017). Yao et al. (2012) reported that microporous biochar could accumulate $\mathrm{NO}_{3}{ }^{-}$and $\mathrm{NH}_{4}{ }^{+}$ through physisorption, which also effectively reduced the inorganic $\mathrm{N}$ leaching. However, the field experiments have led to inconclusive or contrasting results because of their spatiotemporal differences, so that techniques that seemed promising in the lab or in individual experiments failed to translate to large-scale applications. For example, trial experiments of NIs applications showed positive effects in some regions but negative or no effects in others (Qiao et al., 2015). The application of biochar and other chemical treatments should be used cautiously until further information is available on their economic feasibility and their effects on nutrient adsorption ratios of crops, exchangeable $\mathrm{N}$ in soil (Sika and Hardie, 2014) and ecotoxicology. In our previous study, using liquid state fermentation of sweet potato starch wastewater (SPSW) and solid-state fermentation of paddy straw with application of Trichoderma viride, we could significantly minimize the required fertilizer inputs and reduce $\mathrm{N}_{2} \mathrm{O}$ emissions in tea plantations (Xu et al. 2014). However, how the application of T. viride biofertilizer affects $\mathrm{N}$ leaching is still unknown.

Nitrogen leaching losses from tea plantations occurred mainly through the migration of $\mathrm{N}$ in soil interflow during rain; $\mathrm{N}$ accounting systems generally include the soil interflow volume and $\mathrm{N}$ concentration (mainly for $\mathrm{NO}_{3}{ }^{-}$) measurements. WaSiM-ETH (water balance simulation model) is a widely used physical-based hydrological model, which has been validated for simulating the interflow process during rainfall events, quantifying pollution migration or soil nutrients and representing the leaching process (Schulla and Jasper, 2007). The soil interflow volume was based on hilly subtropical climate and various local topographic features (e.g., gradient, soil properties, terrain, vegetation, and land management practices). The $\mathrm{NO}_{3}{ }^{-}$concentration was commonly tested and analyzed after the collection of water samples by in situ lysimeter units (Sørensen and Jensen, 2013).
Therefore, the aims of this study were (i) to investigate the annual relationship between precipitation and the volume of soil leaching under different fertilization conditions and (ii) to quantify the effect of $T$. viride biofertilizer and urea (representative of chemical fertilizer) application to tea cultivation by monitoring the leaching of $\mathrm{N}$ (particularly $\mathrm{NO}_{3}{ }^{-}$).

\section{Materials and methods}

\section{Experimental site}

The trial test was conducted at the Changsha Research Station for Agricultural and Environmental Monitoring (CRSAEM), located in the catchment of the Jinjing River in north eastern Changsha, Hunan (Fig. 1; $28^{\circ} 32^{\prime} 50^{\prime \prime} \mathrm{N}, 113^{\circ} 19^{\prime} 58^{\prime \prime} \mathrm{E}$, and 50-430 $\mathrm{m}$ a.s.l.). The soils within the plot were classified as Ultisols derived from granite parent material, which had been degrades after long-term waterlogging and reduction of iron oxide under anaerobic conditions (USDA taxonomy). The spatial patterns of different land uses in CRSAEM comprised woodlands (Pinus massoniana Lamb and Cunninghamia lanceolata Lamb. Hook.), paddy fields (double-cropping rice fields), and tea plantations, taking up $65.5,25.1$, and $3.4 \%$, respectively. Less than $0.5 \%$ of the upland area was used to cultivate sweet potato in order to produce commercial starch. The region covers $135 \mathrm{~km}^{2}$ of the watershed and experiences a typical subtropical monsoon climate; the weather is relatively temperate and had an annual mean temperature of $17.5^{\circ} \mathrm{C}$ and an annual mean precipitation of $1330 \mathrm{~mm}$ from 1979 to 2010 (Li et al. 2013). The tea fields, paddy fields, and sweet potato fields were fertilized at the average rates of 450,300 , and $250 \mathrm{~kg} \mathrm{~N} \mathrm{ha}^{-1}$ year $^{-1}$, respectively, while the woodland ecosystem was unfertilized and undisturbed.

\section{Experimental design}

The biofertilizer was prepared with $T$. viride EBL13, SPSW, and rice straw, which were applied for production of spore suspension for starter inoculums, liquid fermentation of mycelium, and solid fermentation of $T$. viride biofertilizer, respectively. The physicochemical properties of SPSW and biofertilizer were analyzed based on the Standards of Microbial Inoculants in Agriculture (SMIA, national standard of China, GB 20287-2006), and the results demonstrated that both ingredients used in this study were safe and practicable for their intended use.

To compare the effect of $T$. viride biofertilizer and chemical fertilizer on $\mathrm{N}$ leaching, spatially separated $60 \mathrm{~m}^{2}\left(6 \times 10 \mathrm{~m}^{2}\right)$ plots that were planted with 3-year-old tea (Camellia sinensis cv.) were treated with different fertilizers as follows: (1) CK0, no fertilizer applied; (2) CNH450 and CNL225, the chemical fertilizer treatments (values behind the capital letters mean the 


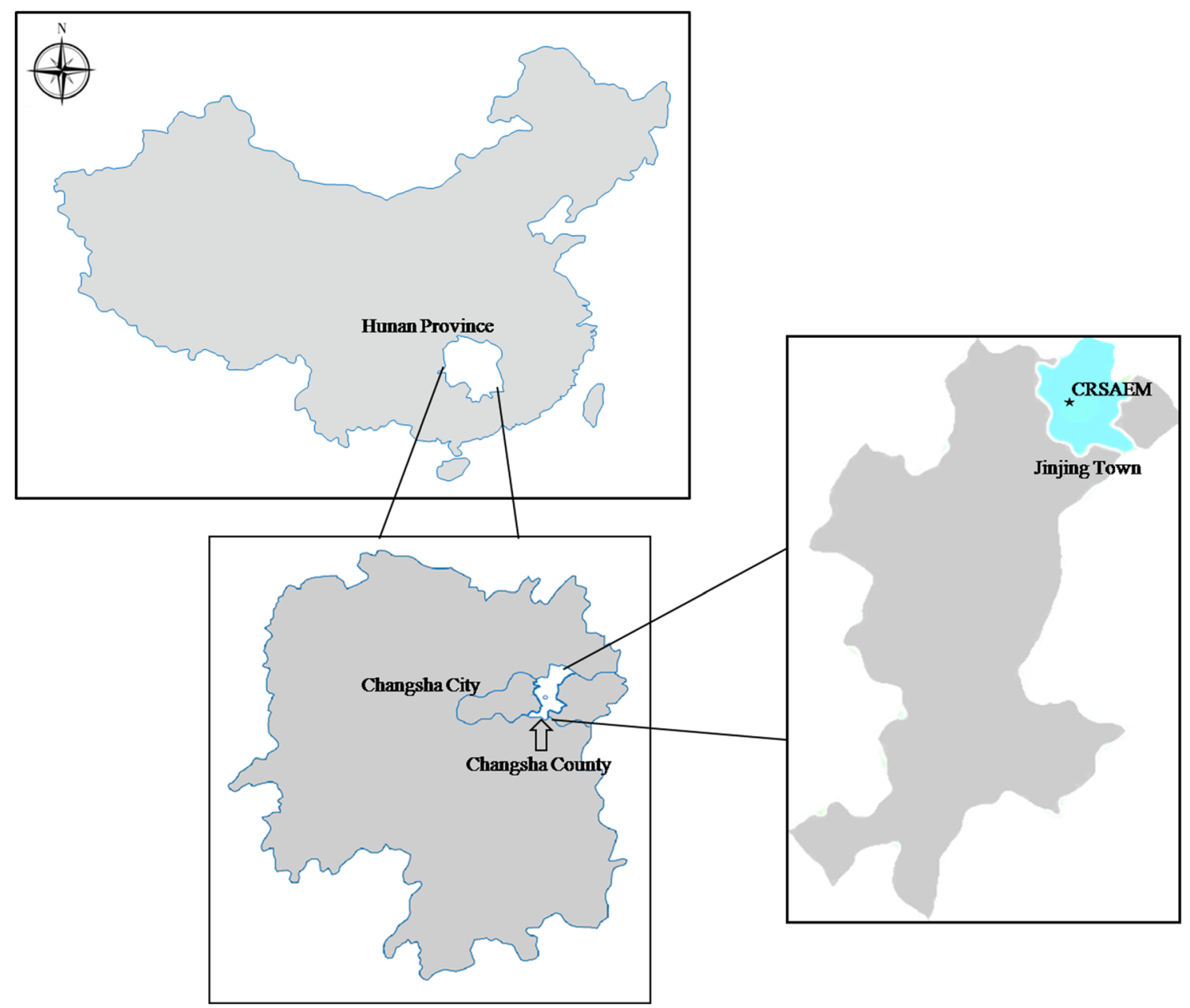

Fig. 1 The site of Changsha Research Station for Agricultural and Environmental Monitoring (CRSAEM)

annual dosage of fertilization, with units of $\mathrm{kg} \mathrm{N} \mathrm{ha}^{-1}$ year ${ }^{-1}$ ); (3) BFH225 and BFL113, the biofertilizer treatments, which were applied at 50,000 and $25,000 \mathrm{~kg} \mathrm{ha}^{-1}$ year $^{-1}$, containing equal or half the N content of CNL225, respectively; and (4) RMH225 and RMH113, raw materials (SPSW and rice straw) alone, applied at 50,000 and $25,000 \mathrm{~kg} \mathrm{ha}^{-1} \mathrm{year}^{-1}$. The fertilizers (including biofertilizer and chemical fertilizer) were applied in split applications, such that $20 \%$ of the total $\mathrm{N}$ was first applied on November 12, 2010, followed by $60 \%$ on March 1, 2011, and $20 \%$ on September 1, 2011 in all treated fields. Five sets of in situ lysimeter were installed by five-point sampling method in each treatment plot $\left(60 \mathrm{~m}^{2}, 6 \times 10 \mathrm{~m}^{2}\right)$ for collecting the precipitation water. Soil samples of $0-20 \mathrm{~cm}$ in each spot were collected to analyze the ammonia and nitrate concentrations. More details about the preparation process and experimental design can be found in Xu et al. (2014).

\section{Monitoring $\mathbf{N}$ leaching}

The $\mathrm{N}$ leaching was continuously monitored from January to December 2011. The amount of $\mathrm{N}$ leached from tea fields was collected by in situ lysimeters, which were located in the fivespot tea plants in each treated plot and uniformly constructed to a depth of $60 \mathrm{~cm}$ when measured from the tunnel bottom to soil surface (Fig. 2). Also, a horizontal tunnel $(40 \mathrm{~cm} \times 50 \mathrm{~cm} \times 5 \mathrm{~cm})$ was dug for settling a leachate collection plate $(40 \mathrm{~cm} \times 50 \mathrm{~cm})$ into the vertical sides of the collection tube. Collected leachate was first filtrated by a filtrating net placed in the plate to prevent debris from blocking the pipes and then drained through a plastic pipes into the collection tube via a side hole, which was punched at a lower height than that at the bottom of the leachate collection plate. The leachate collection tubes and plates in the fields were all built from PVC material with a diameter of $10 \mathrm{~cm}$. In addition, polyvinyl chloride pipes of $5 \mathrm{~cm}$ diameter were installed at the bottom of the collection tubes to allow the leachate to be discharged by an air pump vacuum extraction system (Li et al., 2007). The accumulated leachate was collected on the first and fifteenth of each month, and the local climate and fundamental soil indexes were simultaneously recorded. All procedures of devices installation did not disturb the primitive soil structure. The $\mathrm{N}$ concentrations of leachate 
Fig. 2 In situ leachate collection mounting system in the tea field

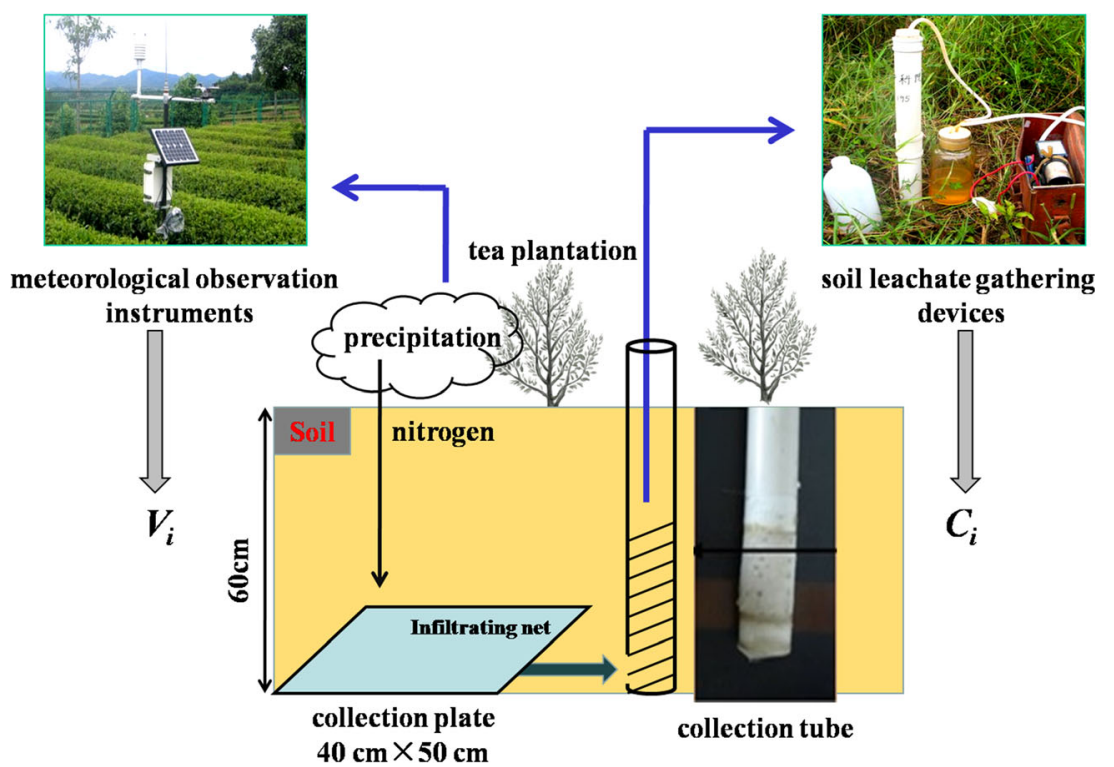

soil property, topography, vegetation coverage, and also the 0 $20 \mathrm{~cm}$ topsoil moisture had been recorded, and the data can be seen in Fu et al. (2012).

\section{Data analysis}

Under the WaSiM-ETH, all data analyses presented were established in terms of the Design Expert software version and SPSS 19.0. Stepwise linear regression followed by monthly $\mathrm{N}$ leaching as the dependent variable was conducted to judge the extent of influence among $\mathrm{NO}_{3}{ }^{-}-\mathrm{N}$ and $\mathrm{NH}_{4}{ }^{+}-\mathrm{N}$

Table 1 Precipitation and soil interflow under different fertilization patterns in 2011

\begin{tabular}{lcccc}
\hline Month & $\begin{array}{l}\text { Precipitation } \\
(\mathrm{mm})\end{array}$ & $\begin{array}{l}\text { Soil } \\
\text { interflow } \\
\text { at CK }(\mathrm{mm})\end{array}$ & $\begin{array}{l}\text { Soil } \\
\text { interflow } \\
\text { at OF }(\mathrm{mm})\end{array}$ & $\begin{array}{l}\text { Soil } \\
\text { interflow } \\
\text { at CF }(\mathrm{mm})\end{array}$ \\
\hline Jan & 2.43 & 7.91 & 2.76 & 38.70 \\
Feb & 20.32 & 0.21 & 0.3 & 3.34 \\
Mar & 39.22 & 0.02 & 0.05 & 0.92 \\
Apr & 158.91 & 60.36 & 25.72 & 81.82 \\
May & 73.4 & 37.98 & 58.62 & 26.14 \\
Jun & 317.76 & 199.31 & 119.23 & 122.47 \\
Jul & 85.59 & 64.33 & 134.69 & 52.67 \\
Aug & 182.28 & 59.55 & 51.99 & 82.42 \\
Sep & 44.22 & 3.23 & 6.87 & 4.03 \\
Oct & 52.53 & 10.94 & 1.82 & 10.41 \\
Nov & 47.22 & 0.1 & 0.02 & 2.00 \\
Dec & 10.74 & 0 & 0 & 0.24 \\
Total & 1034.62 & 443.94 & 402.07 & 425.16 \\
\hline
\end{tabular}

$C K$ control group (no additional fertilization), $O F$ organic fertilizer treatment, $C F$ chemical fertilizer treatment 
Fig. 3 Monthly precipitation and estimated soil interflow for different treatments in the tea field using the WaSiM-ETH in 2011

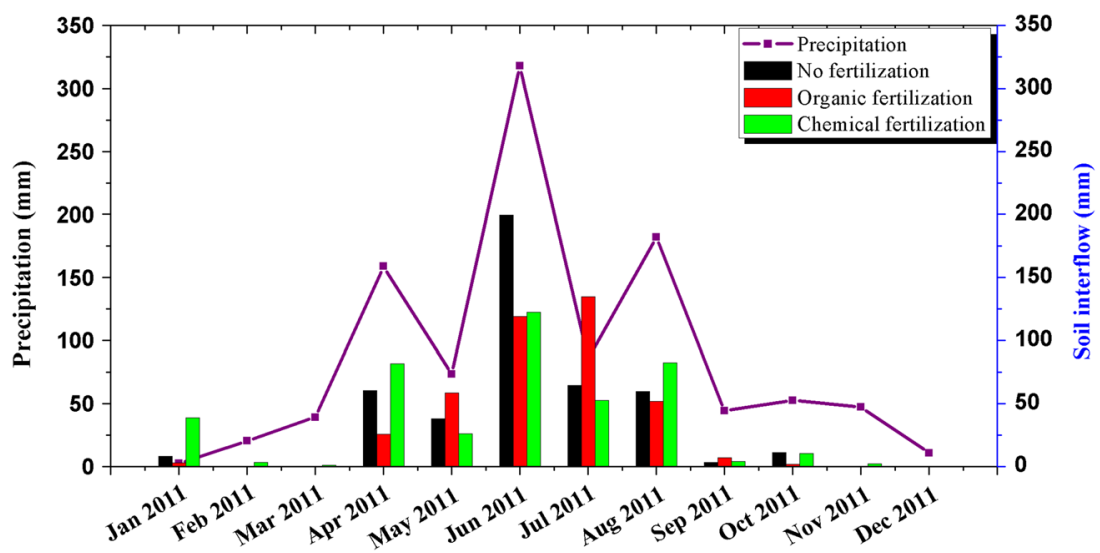

concentrations of soil and soil interflow in different treatments, and $p<0.05$ was considered significant between individual treatments. All figures in this study were edited by Origin Pro 8.0.

\section{Results and discussion}

\section{Precipitation and soil interflow}

The quantity of soil interflow in tea fields was estimated by the distributed hydrological model operated under WaSiM-ETH, while the precipitation was recorded by a small meteorological observatory. The monthly precipitation ranged from a minimum of $2.43 \mathrm{~mm}$ in January to a maximum of $317.76 \mathrm{~mm}$ in June; annual precipitation amounted to $1034.6 \mathrm{~mm}$ (Table 1). Leaching phenomenon principally took place during April, June, and August, which were coincident with intense precipitation. Soil interflow quantities under organic fertilization (OF, corresponding to RMH225 as illustrated in the "Experimental design" section) and chemical fertilization (CF, corresponding to CNL225) treatments were low but exhibited minor differences when compared with no fertilization (CK). Soil interflow quantity was positively correlated with precipitation (Fig. 3). The soil interflow under OF increased from April to July and then decreased afterwards. The cause of this trend was not clear; however, it might be partially because of the liquid state organic fertilizer, which could effectively enhance the plant nutrient uptake and soil moisture when compared with CK after fertilization in March. However, excessive liquid fertilizer was difficult for plants to take up and the residual fertilizers infiltrated through the soil by eluviation. Because of low precipitation, soil interflow was modest in other months, apart from the sudden percolation of water that occurred in January under CF treatment, which was caused by water saturation in the surface soil after irrigation. It is also worth noting that because the exact values of soil interflow generally needs a long-term in situ observation and the simulation process on WaSiM-ETH is particularly susceptible to the complexity and anisotropy in farmland ecosystem, therefore the estimated soil interflow applied here was used to confirm the trend of reducing nitrogen leaching by $T$. viride biofertilizer.
Fig. 4 Change in nitrate $\mathrm{NO}_{3}{ }^{-}$ $\mathrm{N})$ concentrations under different treatments in the tea field. CK: control group, no fertilization; RMH225 and RMH113: raw materials (sweet potato starch wastewater and rice straw) at 50,000 and $25,000 \mathrm{~kg} \mathrm{ha}^{-1}$ year $^{-1}$ application rate; $\mathrm{BFH} 225$ and BFL113: biofertilizer at 50,000 and $25,000 \mathrm{~kg} \mathrm{ha}^{-1}$ year $^{-1}$ application rate; $\mathrm{CNH} 450$ and CNL225: chemical fertilizer at 450 and $225 \mathrm{~kg} \mathrm{~N}^{-1}$ year $^{-1}$ application rate)

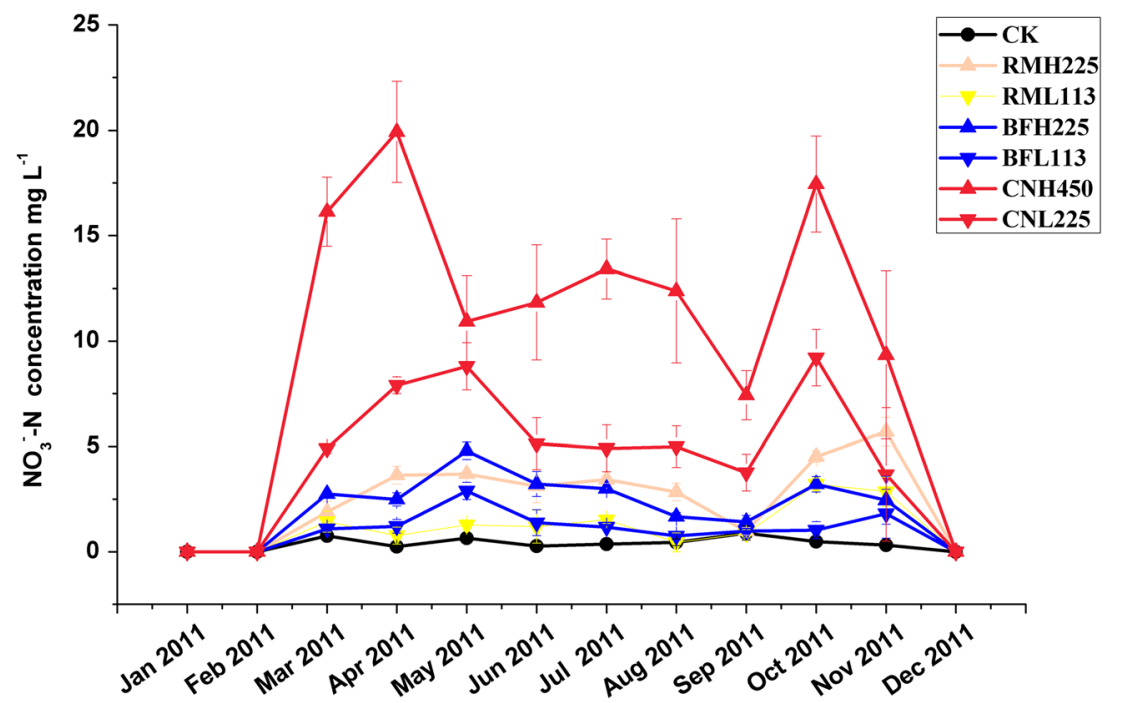


Table 2 Total annual nitrogen application and leaching loss for different treatments in the tea field

\begin{tabular}{lccl}
\hline Treatment & $\begin{array}{l}\text { Annual application } \\
\left(\mathrm{kg} \mathrm{ha}^{-1}\right)\end{array}$ & $\begin{array}{l}\text { Annual leaching } \\
\text { losses }\left(\mathrm{kg} \mathrm{ha}^{-1}\right)\end{array}$ & $\begin{array}{l}\text { Fraction } \\
\text { leached (\%) }\end{array}$ \\
\hline CK & 0 & $1.51^{\mathrm{a}}$ & - \\
RMH225 & 225 & $13.07^{\mathrm{c}}$ & 5.81 \\
RML113 & 113 & $4.76^{\mathrm{b}}$ & 4.21 \\
BFH225 & 225 & $12.35^{\mathrm{c}}$ & 5.49 \\
BFL113 & 113 & $5.70^{\mathrm{b}}$ & 5.04 \\
CNH450 & 450 & $53.38^{\mathrm{e}}$ & 11.86 \\
CNL225 & 225 & $22.33^{\mathrm{d}}$ & 9.93 \\
\hline
\end{tabular}

CK: control group, no fertilization; RMH225 and RMH113: raw materials (sweet potato starch wastewater and rice straw) at 50,000 and $25,000 \mathrm{~kg} \mathrm{ha}^{-1}$ year $^{-1}$ application rate; BFH225 and BFL113: biofertilizer at 50,000 and 25,000 kg ha ${ }^{-1}$ year $^{-1}$ application rate; CNH450 and CNL225: chemical fertilizer at 450 and $225 \mathrm{~kg} \mathrm{~N} \mathrm{ha}^{-1}$ year $^{-1}$ application rate. The same superscript letter (a-e) in the column indicates that the differences in annual leaching losses are not significant $(\mathrm{p}<0.05)$

\section{Leaching study}

In this study, only the variation in $\mathrm{NO}_{3}{ }^{-} \mathrm{N}$ concentration was presented because the concentration of $\mathrm{NH}_{4}{ }^{+}-\mathrm{N}$ was less than the detection limit-concentration in all samples. The percolation water leaching below the rhizosphere, namely the soil interflow described in the "Precipitation and soil interflow" section, was collected by lysimeters set in the field and the $\mathrm{NO}_{3}{ }^{-}-\mathrm{N}$ concentrations determined for the different fertilizer treatments (Fig. 4). Factors such as precipitation, soil texture, and fertilizer application rate could affect the $\mathrm{N}$ concentration in the drainage water. $\mathrm{N}$ fertilizer applications increased the $\mathrm{NO}_{3}{ }^{-}-\mathrm{N}$ concentration in drainage water markedly when compared with the unfertilized control. In particular, application of chemical fertilization (urea) resulted in greater concentrations of $\mathrm{NO}_{3}{ }^{-}-\mathrm{N}$ than the other treatments.

For CNH450 (high-N treatment of $450 \mathrm{~kg} \mathrm{~N}^{-1}$ year $^{-1}$ ) and CNL225 (low-N treatment of $225 \mathrm{~kg} \mathrm{~N} \mathrm{ha}^{-1}$ year $^{-1}$ ), the $\mathrm{NO}_{3}{ }^{-} \mathrm{N}$ concentration fluctuated within a broad range of 0.15-16.31 and 0.05-6.46 $\mathrm{mg} \mathrm{L}^{-1}$ (not included naught concentrations) (Fig. 4). This led to an accumulated annual $\mathrm{NO}_{3}{ }^{-}$ loss of $53.38 \pm 0.89$ (mean and standard deviation) and $22.33 \pm 0.40 \mathrm{~kg} \mathrm{~N} \mathrm{ha}^{-1}$ year $^{-1}$, accounting for 11.86 and $9.93 \%$ of the total $\mathrm{N}$ input, respectively. Many studies have confirmed that the combined effect of both precipitation and chemical fertilizer application will aggravate $\mathrm{N}$ leaching loss, which is consistent with our results. It has been reported that soil $\mathrm{N}$ concentration decreased rapidly after chemical fertilization (Xu et al. 2014); however, we found that $\mathrm{N}$ concentration increased substantially in drainage water in relation to rainfall events. However, under BFH225 and BFL113 treatments, the $\mathrm{N}$ losses were below the high levels of the CNH450 and CNL225 treatments throughout the experiment, which is consistent with the conclusion of Shoresh et al. (2010) that biofertilizers could induce increased $\mathrm{N}$ use efficiency in plants. Although raw material treatments (RM) can provide a good opportunity for biofertilizer fermentation to suppress $\mathrm{N}_{2} \mathrm{O}$ emissions (Xu et al. 2014), and simultaneously to suppress the $\mathrm{N}$ leaching losses based on our measurements, it takes much longer time for straw decomposing in soils. Additionally, straw incorporation and applied paddy straw and organic wastewater can greatly hamper crop root penetration, causing $\mathrm{N}$ deficiency disease, weed problems, and low yield (Xu et al. 2014).

The relatively low $\mathrm{NO}_{3}{ }^{-}-\mathrm{N}$ concentration and high leaching loss observed in the same month was because of
Fig. 5 Change in $\mathrm{NO}_{3}{ }^{-}-\mathrm{N}$ leaching under different treatments in the tea field. CK: control group, no fertilization; RMH225 and RMH113: raw materials (sweet potato starch wastewater and rice straw) at 50,000 and $25,000 \mathrm{~kg} \mathrm{ha}^{-1}$ year $^{-1}$ application rate; $\mathrm{BFH} 225$ and BFL113: biofertilizer at 50,000 and $25,000 \mathrm{~kg} \mathrm{ha}^{-1}$ year $^{-1}$ application rate; $\mathrm{CNH} 450$ and CNL225: chemical fertilizer at 450 and $225 \mathrm{~kg} \mathrm{~N} \mathrm{ha}^{-1}$ year $^{-1}$ application rate)

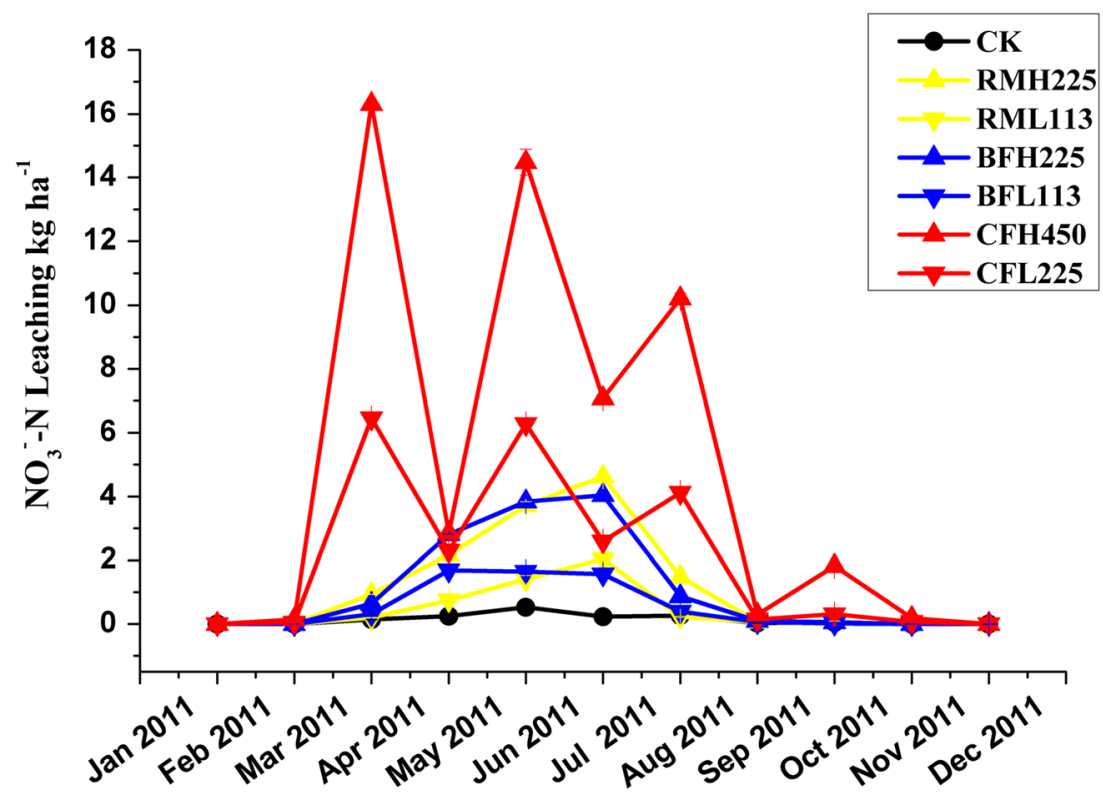


Fig. 6 Regression analyses of $\mathrm{NO}_{3}{ }^{-}$-N leaching amounts with a soil interflow, b ammonium

$\left(\mathrm{NH}_{4}{ }^{+}-\mathrm{N}\right)$ concentration in soil, and $\mathbf{c} \mathrm{NO}_{3}{ }^{-} \mathrm{N}$ concentration in soil. Regression linear equation and goodness of fit $\left(R^{2}\right)$ were also shown in each plot a

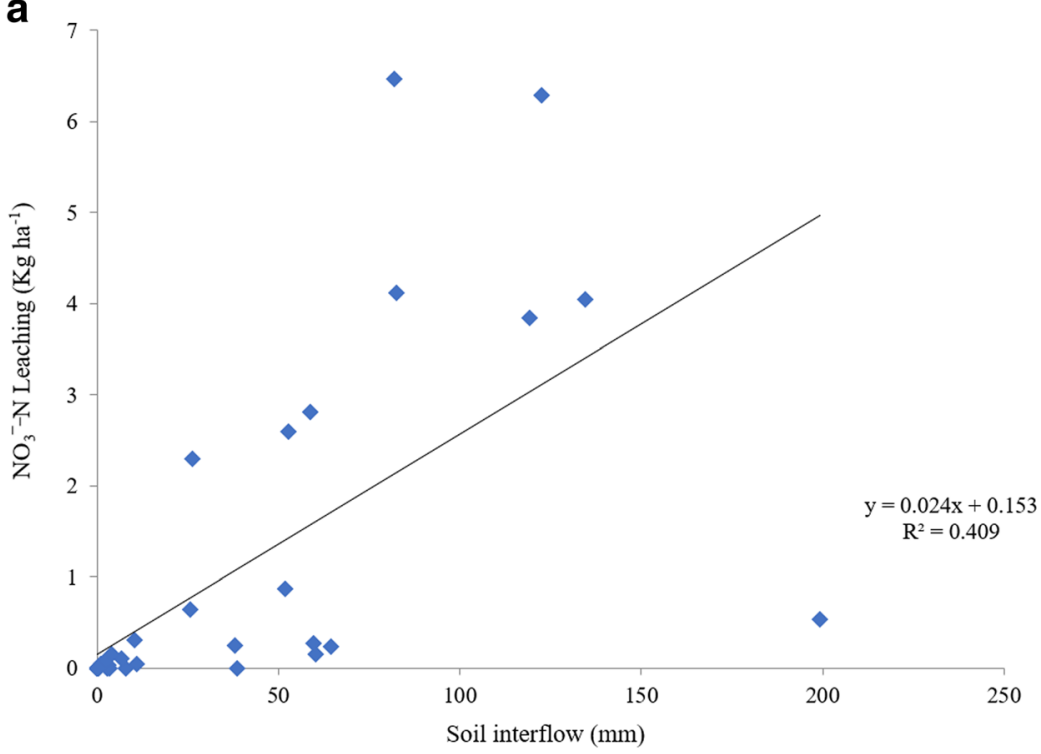

b

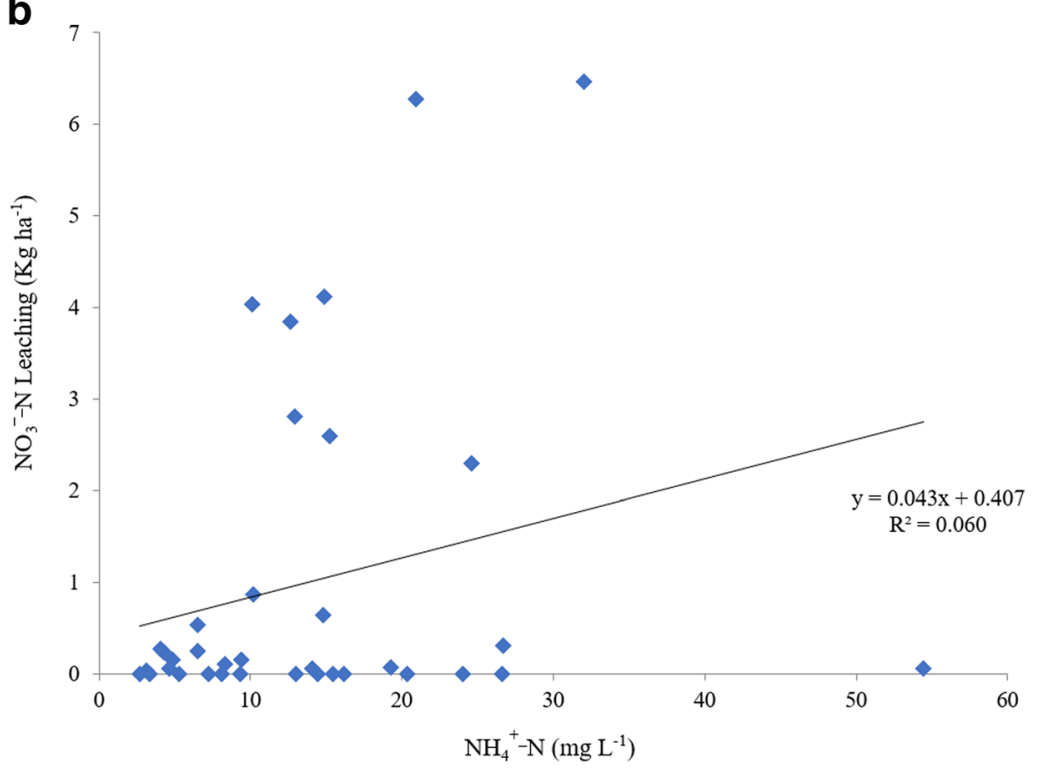

C

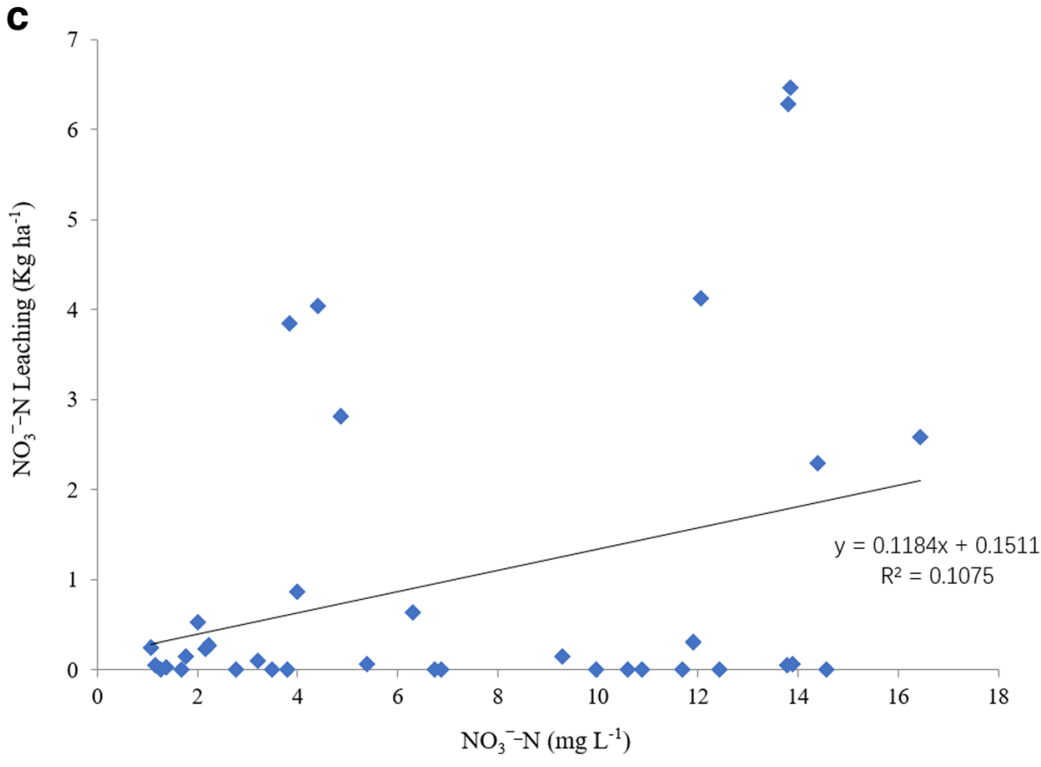


the dilution effect of massive precipitation. In temperate districts, the dynamics of $\mathrm{NO}_{3}{ }^{-}$leaching are influenced by the alternation of dry and wet cycles, which suggests that soil $\mathrm{NO}_{3}{ }^{-}$accumulated during dry periods would result in larger $\mathrm{NO}_{3}{ }^{-}$losses in the following wet period (Randall and Mulla 2001; Sun et al. 2008). The annual N losses were also influenced by $\mathrm{N}$ application rate. In all three treatment types (chemical fertilizer, raw materials, or biofertilizer), higher $\mathrm{N}$ application rates resulted in larger $\mathrm{N}$ losses to varying degrees (Table 2). Li et al. (2007) similarly found that superfluous $\mathrm{N}$ losses could be partially ascribed to excessive $\mathrm{N}$ application rates across the Northern China Plain. In addition, when compared with the gross losses under $\mathrm{CK}$, N losses under CNH450 and CNL225 increased by 35.4-fold and 14.8-fold, respectively, while $\mathrm{N}$ losses under BFH225 and BFL113 only increased by 8.2 -fold and 3.8-fold respectively, showing that T. viride biofertilizer could significantly reduce the $\mathrm{N}$ losses in tea fields. The possible mechanisms of action of $T$. viride biofertilizer are as follows: (1) promotion of root growth and nutrient uptake of fast-growing tea plants (Shoresh et al. 2010), directly reducing surplus $\mathrm{N}$ in the soil to prevent $\mathrm{N}$ leaching; (2) inhibition of nitrification or hydrolytic processes. Zhong et al. (2007) indicated that soil nitrification was more intense under application of $\mathrm{N}$ fertilizer than without $\mathrm{N}$ fertilizer. The $\mathrm{NO}_{3}{ }^{-}-\mathrm{N}$ produced during nitrification might be inhibited by the presence of $T$. viride and retained in the soil (Cai and Zhao, 2009) or emitted into the atmosphere as $\mathrm{N}_{2}$ through denitrification and (3) low $\mathrm{NO}_{3}{ }^{-}-\mathrm{N}$ release rate. Rather than chemical fertilizers, biofertilizers as well as organic fertilizers were highly recommended for their slow production of $\mathrm{NO}_{3}{ }^{-}-\mathrm{N}$ (Liu et al. 2012).

\section{Regression analysis}

As with the $\mathrm{NO}_{3}{ }^{-} \mathrm{N}$ and $\mathrm{NH}_{4}{ }^{+}-\mathrm{N}$ concentrations of soil, three typical sets of soil interflow data under $\mathrm{CK}, \mathrm{OF}$, and $\mathrm{CF}$ treatments (corresponding to Table 2) were selected for clarifying the interrelation with gross $\mathrm{N}$ leaching. Linear regression analysis of the three factors led to the primary conclusion that only soil interflow was related to $\mathrm{NO}_{3}{ }^{-}-\mathrm{N}$ leaching (Figs. 5 and 6). However, since $\mathrm{NH}_{4}{ }^{+}-\mathrm{N}$ was more likely to be converted to
$\mathrm{NO}_{3}{ }^{-} \mathrm{N}$ than remain in the soil, separate analysis of them might result in multicollinearity and lead to an inaccurate model as a consequence.

Based on the above conclusion, we conducted a further analysis with stepwise linear regression (Table 3 ). With different dimensions against independent variables, nonstandardized coefficients were adapted. The stepwise regression showed that soil interflow and nitrate concentration gave the best fit to the $\mathrm{N}$ leaching data and a multiregression equation yielded $y=0.025 x_{1}+0.137 x_{2}-0.874\left(y\right.$ is $\mathrm{NO}_{3}{ }^{-}-\mathrm{N}$ leaching, $x_{1}$ is soil interflow, and $x_{2}$ is $\mathrm{NO}_{3}{ }^{-} \mathrm{N}$ concentration, $\left.R^{2}=0.553\right)$. The multiple regression demonstrated that a significant positive effect existed between $\mathrm{N}$ leaching and both soil interflow and the concentration of $\mathrm{NO}_{3}{ }^{-} \mathrm{N}$ in the soil. These results concurred with a recent assessment that showed that soil permeability, $\mathrm{N}$ application rate, and climate factors largely regulated $\mathrm{N}$ leaching (Cabrera et al. 2007), and they are also consistent with the conclusions in several previous studies (Li et al. 2007; Sun et al. 2008). The poor correlation between $\mathrm{N}$ leaching losses and soil $\mathrm{NH}_{4}{ }^{+}-\mathrm{N}$ concentration suggested that the $T$. viride biofertilizer prepared in our study possessed the ability to restrain $\mathrm{NH}_{4}{ }^{+}$-N nitrification when compared with chemical fertilizer, leading to reduced $\mathrm{N}$ leaching. The other main driver of $\mathrm{N}$ leaching, the soil interflow, has a close relationship with precipitation and soil type. Therefore, this provides options for controlling $\mathrm{N}$ leaching by applying rational irrigation rates, avoiding soils with inferior water retention capacity, and consolidating soil management in agricultural planning (Krol et al. 2016).

\section{Conclusions and perspectives}

We found that $T$. viride biofertilizer could regulate not only the $\mathrm{N}$ losses from $\mathrm{N}_{2} \mathrm{O}$ emissions but also $\mathrm{N}$ leaching in the tea field. Plots with high-N and low-N Chemical fertilizer treatments led to an annual nitrogen leaching loss of $53.38 \pm 0.89$ and $22.33 \pm 0.40 \mathrm{~kg} \mathrm{~N} \mathrm{ha}^{-1}$ year $^{-1}$, accounting for 11.86 and 9.93\% of the total $\mathrm{N}$ input, and 34.4-fold and 13.8-fold higher than CK treatment, respectively. In comparison with the same rate of application of chemical N fertilizer (as urea; CNL225;
Table 3 Stepwise linear regression analysis output

\begin{tabular}{|c|c|c|c|c|c|c|}
\hline \multicolumn{2}{|c|}{ Model } & \multicolumn{2}{|c|}{ Non-standardized coefficients } & \multirow[t]{2}{*}{$t$ value } & \multirow[t]{2}{*}{ Sig. } & \multirow[t]{2}{*}{$R^{2}$} \\
\hline & & $B$ & SE & & & \\
\hline 1 & $\begin{array}{l}\text { Intercept } \\
\text { Soil interflow }\left(x_{1}\right)\end{array}$ & $\begin{array}{l}0.154 \\
0.024\end{array}$ & $\begin{array}{l}0.293 \\
0.005\end{array}$ & $\begin{array}{l}0.524 \\
4.858\end{array}$ & $\begin{array}{l}0.604 \\
0\end{array}$ & 0.410 \\
\hline \multirow[t]{2}{*}{2} & $\begin{array}{l}\text { Intercept } \\
\text { Soil interflow }\left(x_{1}\right)\end{array}$ & $\begin{array}{l}-0.874 \\
0.025\end{array}$ & $\begin{array}{l}0.409 \\
0.004\end{array}$ & $\begin{array}{l}-2.139 \\
5.734\end{array}$ & $\begin{array}{l}0.04 \\
0.00\end{array}$ & \multirow[t]{2}{*}{0.553} \\
\hline & Nitrate concentration $\left(x_{2}\right)$ & 0.137 & 0.042 & 3.252 & 0.003 & \\
\hline
\end{tabular}

$B$ (regression coefficient) and SE (standard error) are presented for each model, together with the $t$ value, Sig. ( $P$ value), and $R^{2}$ (goodness of fit) 
$225 \mathrm{~kg} \mathrm{~N} \mathrm{ha}^{-1}$ year $^{-1}$ ), the application of $T$. viride biofertilizer (BFH225) resulted in a $44.7 \%$ reduction in $\mathrm{N}$ leaching. We hypothesize that biofertilizers have the ability to enhance crop quality and soil texture indirectly by promoting microbial metabolism, but not through the immediate application of absorbable or available nutrients to plants. This is because T. viride biofertilizer has the potential to promote root growth and nutrient uptake of fast-growing tea plants, inhibit nitrification or hydrolytic processes, and release $\mathrm{NO}_{3}{ }^{-} \mathrm{N}$ at a slow rate; certain mechanism will be investigated in subsequent experiments. Besides, through stepwise linear regression, we identified soil nitrate concentration and soil interflow were responsible for $\mathrm{N}$ leaching.

Our research was undertaken in a major tea producing areas of the central subtropical zone in China. In addition to tea plantations ( $3.4 \%$ of the land area), $25.1 \%$ of the whole region is used for rice production in paddy fields and $<0.5 \%$ for sweet potatoes. The region produces an annual output of about $12,000 \mathrm{t}$ sweet potato starch wastes, 30,240 t rice straws, and $10.2 \mathrm{t} \mathrm{NO}_{3}{ }^{-}$leaching. These three pollutants have become crucial contributors to regional water and atmospheric contamination. However, by using liquid-state fermentation of SPSW and solid-state fermentation of paddy straw by $T$. viride, annual production of $6000 \mathrm{t}$ biofertilizers equivalent to $27 \mathrm{t} \mathrm{N}$ fertilizers can be provided to tea plantations. This can reduce pollution from the wastes and replace some functions of synthetic $\mathrm{N}$, minimizing synthetic inputs of fertilizer in tea cultivation. Thus, the process described here using SPSW and rice straw for mass-scale production of $T$. viride biofertilizer is a feasible and cost-effective approach for minimizing synthetic inputs of fertilizer, reducing $\mathrm{N}$ leaching and cumulative $\mathrm{N}_{2} \mathrm{O}$ emissions, saving farmers' money in increasingly expensive chemical fertilizers and developing best management practices for tea fields in subtropical areas of central China.

Funding information This work was supported by the National Science Fund Projects (Nos. 41371266 and 31670507), the Innovation in Cross-functional Team Program of the Chinese Academy of Sciences (No. 2015), the Key Research Program of Chinese Academy of Sciences (No. ZDRW-ZS-2016-5), and the Key State Science and Technology Program of China (No. 2015ZX07206-006).

\section{References}

Cabrera VE, Jagtap SS, Hildebrand PE (2007) Strategies to limit (minimize) nitrogen leaching on dairy farms driven by seasonal climate forecasts. Agric Ecosyst Environ 122:479-489. doi:10.1016/j.agee.2007.03.005

Cai ZC, Zhao W (2009) Effects of land use types on nitrification in humid subtropical soils of China. Acta Pedol Sin 46(5):795-801 (in Chinese)

FAO (Food and Agriculture Organization) (2016) FAOSTAT Database collections. FAO, Rome: http://www.faostat.fao.org
$\mathrm{Fu}$ X, Li Y, Su W et al (2012) Annual dynamics of $\mathrm{N}_{2} \mathrm{O}$ emissions from a tea field in southern subtropical China. Plant Soil Environ 58(8): 373-378

Gao S, Xu P, Zhou F et al (2016) Quantifying nitrogen leaching response to fertilizer additions in China's cropland. Environ Pollut 211:241251. https://doi.org/10.1016/j.envpol.2016.01.010

Krol DJ, Jones MB, Williams M et al (2016) The effect of renovation of long-term temperate grassland on $\mathrm{N} 2 \mathrm{O}$ emissions and $\mathrm{N}$ leaching from contrasting soils. Sci Total Environ 560-561:233-240. https:// doi.org/10.1016/j.scitotenv.2016.04.052

Li X, Hu C, Delgado JA et al (2007) Increased nitrogen use efficiencies as a key mitigation alternative to reduce nitrate leaching in north china plain. Agric Water Manag 89:137-147. https://doi.org/10.1016/j. agwat.2006.12.012

Li Y, White R, Chen D, et al (2007) A spatially referenced water and nitrogen management model (WNMM) for (irrigated) intensive cropping systems in the North China Plain. Ecol Modell 203:395423. doi:10.1016/j.ecolmodel.2006.12.011

Li S, Wu X, Xue H et al (2011) Quantifying carbon storage for tea plantations in China. Agric Ecosyst Environ 141:390-398. https:// doi.org/10.1016/j.agee.2011.04.003

$\mathrm{Li} \mathrm{Y,} \mathrm{Fu} \mathrm{X,} \mathrm{Liu} \mathrm{X} \mathrm{et} \mathrm{al} \mathrm{(2013)} \mathrm{Spatial} \mathrm{variability} \mathrm{and} \mathrm{distribution} \mathrm{of} \mathrm{N}_{2} \mathrm{O}$ emissions from a tea field during the dry season in subtropical central China. Geoderma 193-194:1-12. https://doi.org/10.1016/j. geoderma.2012.10.008

Liu C, Wang K, Meng S et al (2011) Effects of irrigation, fertilization and crop straw management on nitrous oxide and nitric oxide emissions from a wheat-maize rotation field in northern China. Agric Ecosyst Environ 140:226-233. https://doi.org/10.1016/j.agee.2010.12.009

Liu Z, Yang J, Yang Z, Zou J (2012) Effects of rainfall and fertilizer types on nitrogen and phosphorus concentrations in surface runoff from subtropical tea fields in Zhejiang, China. Nutr Cycl Agroecosystems 93:297-307. https://doi.org/10.1007/s10705-012-9517-x

Palmer MM, Forrester JA, Rothstein DE, Mladenoff DJ (2014) Conversion of open lands to short-rotation woody biomass crops: site variability affects nitrogen cycling and $\mathrm{N}_{2} \mathrm{O}$ fluxes in the US Northern Lake States. GCB Bioenergy 6:450-464. https://doi.org/ 10.1111/gcbb. 12069

Qiao C, Liu L, Hu S et al (2015) How inhibiting nitrification affects nitrogen cycle and reduces environmental impacts of anthropogenic nitrogen input. Glob Chang Biol 21:1249-1257. https://doi.org/10. $1111 /$ gcb.12802

Randall GW, Mulla DJ (2001) Nitrate nitrogen in surface waters as influenced by climatic conditions and agricultural practices. J Environ Qual 30:337-344. https://doi.org/10.2134/jeq2001.302337x

Ravishankara AR, Daniel JS, Portmann RW (2009) Nitrous oxide (N2O): the dominant ozone-depleting substance emitted in the 21 st century. Science 326(80):123-125. https://doi.org/10.1126/science.1176985

Schulla J, Jasper K (2007) Model description WaSiM-ETH (Water balance Simulation Model ETH). Institute for Atmospheric and Climate Science, Zürich, p 181

Shoresh M, Harman GE, Mastouri F (2010) Induced systemic resistance and plant responses to fungal biocontrol agents. Annu Rev Phytopathol 48:268-269

Sika MP, Hardie AG (2014) Effect of pine wood biochar on ammonium nitrate leaching and availability in a South African sandy soil. Eur J Soil Sci 65:113-119. https://doi.org/10.1111/ejss.12082

Sørensen P, Jensen L (2013) Nutrient leaching and runoff from land application of animal manure and measures for reduction. Anim Manue Recycl Treat Manag 2015:195-210. https://doi.org/10. 1002/9781118676677.ch11

Sun B, Chen D, Li Y, Wang X (2008) Nitrogen leaching in an upland cropping system on an acid soil in subtropical China: lysimeter measurements and simulation. Nutr Cycl Agroecosystems 81:291303. https://doi.org/10.1007/s10705-008-9164-4 
Wang Y, Zhang B, Zepp H (2012) Simulating hydrological processes in a subtropical agricultural catchment using the European distributed hydrological model of WaSiM-ETH. Acta Pedol Sin 49(5):875885 (in Chinese)

Wu D, Senbayram M, Well R, et al (2017) Soil Biology \& Biochemistry Nitrification inhibitors mitigate $\mathrm{N}_{2} \mathrm{O}$ emissions more effectively under straw-induced conditions favoring denitrification. Soil Biol Biochem 104:197-207. https://doi.org/10.1016/j.soilbio.2016.10. 022

Xu S, Fu X, Ma S, et al (2014) Mitigating nitrous oxide emissions from tea field soil using bioaugmentation with a trichoderma viride biofertilizer. Sci World J 2014(1):793752-793752. https://doi.org/ $10.1155 / 2014 / 793752$

Yao Y, Gao B, Zhang M et al (2012) Effect of biochar amendment on sorption and leaching of nitrate, ammonium, and phosphate in a sandy soil. Chemosphere 89:1467-1471. https://doi.org/10.1016/j. chemosphere.2012.06.002

Zerulla W, Barth T, Dressel J et al (2001) 3,4-Dimethylpyrazole phosphate (DMPP) - a new nitrification inhibitor for agriculture and horticulture. An introduction Biol Fertil Soils 34:79-84. https://doi.org/ $10.1007 / \mathrm{s} 003740100380$

Zhang J, Hu K, Li K et al (2017) Simulating the effects of long-term discontinuous and continuous fertilization with straw return on crop yields and soil organic carbon dynamics using the DNDC model. Soil Tillage Res 165:302-314. https://doi.org/10.1016/j.still.2016. 09.004

Zhong W-H, Cai Z-C, Zhang H (2007) Effects of long-term application of inorganic fertilizers on biochemical properties of a rice-planting red soil. Pedosphere 17:419-428. https://doi.org/10.1016/S10020160(07)60051-4 